\title{
Light-induced $\mathrm{pH}$ changes in the intact retinae of normal and early diabetic rats
}

\author{
Andrey V. Dmitriev ${ }^{1}$, Desmond Henderson ${ }^{1}$, and Robert A. Linsenmeier ${ }^{1,2,3}$ \\ Desmond Henderson: d-henderson@northwestern.edu; Robert A. Linsenmeier: r-linsenmeier@northwestern.edu \\ ${ }^{1}$ Department of Biomedical Engineering, 2145 Sheridan Road, Northwestern University, \\ Evanston, IL, 60208-3107, United States \\ 2Department of Neurobiology, 2205 Tech Drive, Northwestern University, Evanston, IL, 60208, \\ United States \\ ${ }^{3}$ Department of Ophthalmology, Northwestern University, 645 North Michigan Avenue, Suite 440, \\ Chicago, IL 60611, United States
}

\begin{abstract}
Double-barreled $\mathrm{H}^{+}$-selective microelectrodes were used to measure local extracellular concentration of $\mathrm{H}^{+}\left(\left[\mathrm{H}^{+}\right]_{\mathrm{o}}\right)$ in the retina of dark-adapted anesthetized Long-Evans rats. The microelectrode advanced in steps of $30 \mu \mathrm{m}$ throughout the retina from the vitreal surface to retinal pigment epithelium and then to the choroid, recording changes in $\left[\mathrm{H}^{+}\right]_{\mathrm{o}}$ evoked by light stimulation. Recordings were performed in diabetic rats 1 to 3 months after intraperitoneal injection of streptozotocin and the results were compared with data obtained in age-matched control animals. Brief light stimulation $(2.5 \mathrm{~s})$ evoked changes of $\left[\mathrm{H}^{+}\right]_{\mathrm{o}}$ with amplitudes of a few $\mathrm{nM}$. Throughout the retina, there was a transient initial acidification for $\sim 200 \mathrm{~ms}$ followed by steady alkalinization, although amplitudes and kinetics of these components were slightly variable in different retinal layers. No significant difference was found when the light-induced $\left[\mathrm{H}^{+}\right]_{\mathrm{o}}$ changes recorded in various retinal layers of early diabetic rats were compared with the $\left[\mathrm{H}^{+}\right]_{\mathrm{o}}$ changes from corresponding layers of control animals. Also, when $\mathrm{H}^{+}$-selective microelectrodes were located in the retinal pigment epithelium (RPE) layer, an increase in $\mathrm{H}^{+}$was recorded, whose time course and amplitude were similar in control and diabetic rats. However, a striking difference between light-induced $\left[\mathrm{H}^{+}\right]_{\mathrm{o}}$ changes in controls and diabetics was observed in the choriocapillaris, in the thin layer $(10-20 \mu \mathrm{m})$ distal to the basal membrane of the RPE. In control rats, choroidal $\left[\mathrm{H}^{+}\right]_{\mathrm{o}}$ decreased in a few cases, but much more often practically did not change. In contrast, diabetic rats demonstrated either an increase (in half of the cases) or no change in choroidal $\left[\mathrm{H}^{+}\right]_{0}$. The data suggest that the active participation of the choroidal blood supply in stabilization of $\left[\mathrm{H}^{+}\right]_{\mathrm{o}}$ could be partially compromised already at early stages of diabetes in rats.
\end{abstract}

Corresponding author: Andrey Dmitriev, andrey.dmitriev@ northwestern.edu.

Disclosure

The authors have no financial interests to disclose.

Publisher's Disclaimer: This is a PDF file of an unedited manuscript that has been accepted for publication. As a service to our customers we are providing this early version of the manuscript. The manuscript will undergo copyediting, typesetting, and review of the resulting proof before it is published in its final citable form. Please note that during the production process errors may be discovered which could affect the content, and all legal disclaimers that apply to the journal pertain. 
Interestingly, it appeared that the acid removal by the choroidal circulation was compromised most after 1 month of diabetes and tended to improve later.

\section{Keywords}

$\mathrm{pH}$; diabetes; streptozotocin; rat; ion-selective microelectrodes; retina; retinal pigment epithelium; choroidal blood supply

\section{Introduction}

Neuronal activity, which depends on movements of ions across a neuronal plasma membrane, is inevitably accompanied by changes in ionic concentrations, both intracellularly and extracellularly. In the retina, changes in extracellular $\mathrm{H}^{+}$concentration $\left(\left[\mathrm{H}^{+}\right]_{\mathrm{o}}\right)$ attract particular interest because of their potential influence on various retinal physiological processes. For instance, it has been hypothesized that light-induced $\left[\mathrm{H}^{+}\right]_{\mathrm{o}}$ changes generated by horizontal cells could mediate feedback inhibition onto cones ((Hirasawa and Kaneko, 2003; Kleinschmidt, 1991) for a recent comprehensive review see (Thoreson and Mangel, 2012))

One reason for $\left[\mathrm{H}^{+}\right]_{\mathrm{o}}$ changes is the movement of $\mathrm{H}^{+}$(and other acids and bases, most importantly $\mathrm{HCO}_{3}{ }^{-}$; we will address this subject in the Discussion) across membranes of retinal neurons due to activity-dependent changes in neuronal membrane potentials, conductances, and rate of ion transporters. In this respect, $\mathrm{H}^{+}$is similar to other ions, like $\mathrm{Na}^{+}$or $\mathrm{K}^{+}$. But in contrast to other ions, new $\mathrm{H}^{+}$ions are constantly generated as a waste product of cellular energy metabolism. Thus, $\mathrm{H}^{+}$is not only moved, but also produced by retinal cells. Constant production of $\mathrm{H}^{+}$creates a non-equilibrium distribution of $\left[\mathrm{H}^{+}\right]_{\mathrm{O}}$ across the retinal layers, resulting in $\left[\mathrm{H}^{+}\right]_{0}$ gradients. When metabolic demand is altered (by light stimulation, for instance), altered $\mathrm{H}^{+}$production will change $\left[\mathrm{H}^{+}\right]_{\mathrm{o}}$. Therefore, there are two principal reasons for activity-dependent changes in $\left[\mathrm{H}^{+}\right]_{\mathrm{O}}-$ "metabolism-dependent" related to alterations of energy metabolism, and "electrogenesis-dependent" associated with electrical activity of the cells. Hereafter, for simplicity we call these metabolic and electrogenic.

The metabolic changes of $\left[\mathrm{H}^{+}\right]_{\mathrm{o}}$ require time to develop. For example, acidification of the retina at the transition between subjective day and night at dusk progresses for an hour (Dmitriev and Mangel, 2001), reflecting the slow pace of the circadian-dependent increase in metabolic demand at night. The light-evoked metabolic $\left[\mathrm{H}^{+}\right]_{\mathrm{o}}$ changes are much faster due to faster shifts in energy demands in this case. But the light-induced alkalinization recorded in the photoreceptor layer still needs at least 3 minutes to reach its maximum (Yamamoto et al., 1992). Accordingly, $\left[\mathrm{H}^{+}\right]_{\mathrm{o}}$ changes recorded during the first few seconds after light onset can hardly have a metabolic component and are assumed to be caused purely by electrogenesis. However, although light-evoked changes in neuronal membrane potentials and conductances could be very fast (a fraction of a second), adjustment of ion transporters could take longer time, so the electrogenic $\left[\mathrm{H}^{+}\right]_{\mathrm{o}}$ changes could possibly last for 10 to 30 seconds, mixing with the metabolic changes of $\left[\mathrm{H}^{+}\right]_{0}$. 
It is important to mention that the rate of metabolic acid production is not necessarily proportional to the total rate of energy production. The suppression of oxidative phosphorylation by cyanide dramatically decreases energy production to a level that is not sufficient to support normal retinal activity, but the acid production nevertheless considerably increases, acidifying the tissue (Dmitriev and Mangel, 2004). The reason for this increase in acid production is the compensatory activation of glycolysis under conditions when the oxidative phosphorylation is restricted or impossible. Because glycolysis produces more $\mathrm{H}^{+}$per ATP generated compared with oxidative phosphorylation, the retina becomes more acidic, even if the total production of ATP decreases. Hypoxia, which also forces energy metabolism to shift toward glycolysis, is also accompanied by acidification, as it has been shown in the intact cat retina (Padnick-Silver and Linsenmeier, 2005; Yamamoto and Steinberg, 1992).

We hypothesize that in diabetes an abundance of glucose shifts retinal energy metabolism toward the more acid-generating glycolysis, leading to increased $\left[\mathrm{H}^{+}\right]_{\mathrm{o}}$. Available experimental data support our hypothesis. Acute hyperglycemia markedly acidifies the normal cat retina (Padnick-Silver and Linsenmeier, 2005). In the very few diabetic cats that were studied, dysregulation of retinal $\mathrm{pH}$ accompanied capillary dropout, and acidosis was found in one animal with earlier background retinopathy (Budzynski et al., 2005)

Our results show an acidification of the dark-adapted rat retina already at early stages of diabetes, 1 to 3 months after streptozotocin (STZ) injection (Dmitriev et al., 2014). This raises a question about whether light-evoked changes in $\mathrm{pH}$ would also be altered at this time. The aim of this paper was to examine light-induced $\left[\mathrm{H}^{+}\right]_{\mathrm{o}}$ changes in different retinal layers, as well as in the RPE layer and in the choroid, in diabetic and control rats. The responses were evoked by brief light stimulation ( 2.5 seconds) that enabled us to minimize the metabolic contribution to $\left[\mathrm{H}^{+}\right]_{\mathrm{o}}$ changes and to focus on the electrogenic component, which more directly characterizes the signaling properties of retinal cells. Comparison of control and diabetic animals could also reveal possible diabetes-related deficiencies in mechanisms responsible for $\mathrm{H}^{+}$homeostasis in the retina.

\section{Material and Methods}

\subsection{Animal preparation}

Animal experiments were performed in accordance with the Association for Research in Vision and Ophthalmology Statement for the Use of Animals in Ophthalmic and Vision Research and were approved by Northwestern University's Institutional Animal Care and Use Committee. Male Long-Evans rats were anesthetized during preparation with 2.5-3\% isoflurane $/ 35 \% \mathrm{O}_{2}$ and during recordings with urethane. After completing surgical preparations, the animal was paralyzed with pancuronium bromide and artificially ventilated. An arterial sample was taken shortly after paralysis for measurement of blood gases $\left(\mathrm{PO}_{2}\right.$ and $\left.\mathrm{PCO}_{2}\right), \mathrm{pH}$ and glucose. Arterial values were adjusted if necessary by changes in the tidal volume provided by the respirator and the fraction of inspired oxygen. Thereafter, arterial samples were taken at $\sim 30$ min intervals and adjusted if necessary to maintain blood values in the normal range of $\mathrm{P}_{\mathrm{a}} \mathrm{O}_{2} \approx 100 \mathrm{mmHg}, \mathrm{P}_{\mathrm{a}} \mathrm{CO}_{2} \approx 40 \mathrm{mmHg}$ and $\mathrm{pHa} \approx 7.4$. Arterial blood pressure was measured via the arterial cannula. Simultaneously, 
animal body temperature and heart rate (from ECG) were measured. Further details of the preparation have been given previously (Lau and Linsenmeier, 2012). 6 control and 8 diabetic rats were studied.

\subsection{Induction of diabetes}

Diabetes was induced with a single intraperitoneal injection of streptozotocin (Axxora LLC, San Diego, CA; $65 \mathrm{mg} / \mathrm{kg}$ rat) in $0.05 \mathrm{~mol} / \mathrm{L}$ sodium citrate buffer ( $\mathrm{pH}$ 5) in a volume of $0.01 \mathrm{~mL} / \mathrm{g}$ rat). Age-matched controls received a single intraperitoneal injection of 0.05 $\mathrm{mol} / \mathrm{L}$ sodium citrate buffer only $(0.01 \mathrm{~mL} / \mathrm{g}$ rat $)$. Rats were weighed weekly, and nonfasting blood glucose levels were measured from the tail vein using a Bayer CONTOUR Meter (Bayer HealthCare LLC, Mishawaka, IN). In diabetics, blood glucose was at least $300 \mathrm{mg} / \mathrm{dl}$ during weekly measurements prior to the $\mathrm{H}^{+}$recordings. Data presented here were obtained from animals after 1 to 3 months of diabetes.

\section{$2.3\left[\mathrm{H}^{+}\right]_{0}$ recordings}

Double-barreled $\mathrm{H}^{+}$-sensitive microelectrodes, which were used to measure extracellular $\mathrm{H}^{+}$ concentration, were constructed using methods described previously for $\mathrm{Ca}^{2+}$-sensitive microelectrodes (Dmitriev et al., 1999b), except that the electrodes were filled with Hydrogen Ionophore I - Cocktail A or Cocktail B (Fluka). One of the barrels served as a reference and the other contained an $\mathrm{H}^{+}$-sensitive liquid. Both ion-selective and reference barrels were backfilled with a simplified Ringer's solution ( $140 \mathrm{mM} \mathrm{NaCl}, 5 \mathrm{mM} \mathrm{KCl}, 10$ $\mathrm{mM}$ HEPES, $\mathrm{pH}=7.4$ ). After filling, the tip of the microelectrode was beveled on micropipette beveler (BV-10, Sutter Instrument Co.), so the microelectrode tip was similar in shape to a medical hypodermic needle. The tip diameter was 5-8 $\mu \mathrm{m}$. The resistance of the $\mathrm{H}^{+}$-selective barrel was $50-70 \mathrm{G} \Omega$; the reference barrel had a resistance of $60-100 \mathrm{M} \Omega$. Electrodes were calibrated in solutions that were similar to the standard Ringer's and had $\mathrm{pH}$ values of 7.0, 7.4 and 7.8. All electrodes were calibrated just before experiments and some of them on the next day as well. The slope of the $\mathrm{H}^{+}$electrodes was close to Nernstian, and the electrode preserved more than $95 \%$ of its sensitivity to $\mathrm{H}^{+}$on the following day. Voltage from the $\mathrm{H}^{+}$barrel was recorded with a high input impedance amplifier (FD-223a, WPI).

The microelectrode was placed inside a metal needle inserted into the eye through the sclera and advanced through the vitreous toward the retina. Both the reference and ion-selective barrel were referenced to an $\mathrm{Ag} / \mathrm{AgCl}$ electrode in the neck. When in the retina, as signaled by a change in the electroretinogram, the electrode was advances in $30 \mu \mathrm{m}$ steps by hydraulic micropositioner (Kopf model 2650). In the figures, the position of the microelectrode in the retina is presented as a percentage of retinal depth, with the inner limiting membrane defined as $0 \%$, and the retinal pigment epithelium (RPE) - as $100 \%$. At each retinal depth, as well as in the RPE layer and just past the RPE in the choriocapillaris, light stimuli of high scotopic illumination (white light, 7.9 lux) and 2.5 seconds in duration were applied. Light-induced electrical responses of both barrels were recorded, digitized and stored in the computer memory. The response of the reference barrel was the local ERG (LERG). To yield a pure $\mathrm{H}^{+}$response, the reference barrel voltage signals was subtracted from the signal from the $\mathrm{H}^{+}$barrel and then the resulting voltage was converted to $\left[\mathrm{H}^{+}\right]$ based on the electrode calibration. The successful subtraction of electrical field potential 
from voltage of the selective barrel was confirmed by complete elimination of a test pulse from the final $\mathrm{H}^{+}$recording. This current pulse $(200 \mathrm{msec})$, which was applied after each light stimulus, was sent across the eye between a macroelectrode placed on the cornea and a reference electrode in the neck. The amplitude of the pulse was set to produce a response of a few $\mathrm{mV}$, and was recorded by both barrels of the microelectrode. Absolute values of $\left[\mathrm{H}^{+}\right]$ were obtained by assuming that the arterial $\left[\mathrm{H}^{+}\right]$measured just before or after each profile was the same as $\left[\mathrm{H}^{+}\right]$in the choroid. The digitizing frequency during recordings was 500 $\mathrm{Hz}$. However, during the processing and plotting responses, each successive 10 points were averaged, thus resulting in an effective digitization frequency of $50 \mathrm{~Hz}$. This was quite enough for both $\mathrm{H}^{+}$responses and the LERG.

In a separate series of experiments, for the sake of comparison, we measured light-induced changes in extracellular $\left[\mathrm{K}^{+}\right]$. The procedures for fabricating $\mathrm{K}^{+}$-sensitive electrodes were the same as for $\mathrm{H}^{+}$-sensitive electrodes, but $\mathrm{K}^{+}$-electrodes were filled with Potassium Ionophore I - Cocktail B (Fluka) sensor and had resistances of 10-20 G $\Omega$.

\section{Results}

\subsection{The general picture of light-induced changes of $\left[\mathrm{H}^{+}\right]_{0}$ in intact rat retina}

Fig. 1A shows the spatial distribution of $\left[\mathrm{H}^{+}\right]_{\mathrm{o}}$ in dark-adapted and light-adapted conditions. To obtain these data, the electrode was advanced until penetration of the RPE, signaled by loss or dramatic reduction of the b- and c-waves of the local ERG, and then slowly withdrawn automatically at a rate of $1 \mu \mathrm{m} / \mathrm{sec}$ to generate the profile. Constant $\mathrm{H}^{+}$ production during energy metabolism results in uneven distribution of $\left[\mathrm{H}^{+}\right]_{0}$. The most acidic region is the outer nuclear layer, at $\sim 60 \%$ of the retinal depth, as found previously in cat retina (Padnick-Silver and Linsenmeier, 2005; Yamamoto and Steinberg, 1992). It is somewhat proximal to the inner segments, which have the largest $\mathrm{O}_{2}$ consumption (and, accordingly, largest energy production) in the retina (Lau and Linsenmeier, 2012). Prolonged light stimulation reduces the energy demand in the distal retina by decreasing $\mathrm{Na}^{+}$leakage into the photoreceptors, e.g. (Ames et al., 1992). As result, the energy production and, consequently, production of $\mathrm{H}^{+}$in the photoreceptor layer decreases, reducing the acidity of the distal retina. No significant changes of $\left[\mathrm{H}^{+}\right]_{\mathrm{o}}$ associated with light adaptation (white light, 79 lux) were recorded in proximal retina.

Fig. 1B illustrates the dynamics of light-induced $\left[\mathrm{H}^{+}\right]_{\mathrm{o}}$ changes in the distal and proximal retina. Light stimulation (white light, 79 lux) led to alkalinization in both distal (65\% depth) and proximal (20\% depth) retina, but the time courses of the changes were very different. In proximal retina, the alkalinization had a transient character developing quickly at the beginning but then recovering toward the dark level. In distal retina, $\left[\mathrm{H}^{+}\right]_{\mathrm{O}}$ decreased slowly but steadily, reaching its minimum only after 3 minutes of illumination.

This general picture of $\left[\mathrm{H}^{+}\right]_{\mathrm{o}}$ distribution in intact rat retina is equally applicable for both normal and diabetic animals although some quantitative differences exist (Dmitriev et al, 2014, 2015). This will be the subject of another paper and is not discussed here. 


\subsection{The metabolic and electrogenic light-induced $\left[\mathrm{H}^{+}\right]_{0}$ changes}

The responses in distal retina to light stimuli with durations of $0.5,1$ and 2 minutes are presented in Fig. 2. In the right column of Fig. 2A are local ERGs (LERGs) recorded simultaneously and at the same location as $\left[\mathrm{H}^{+}\right]_{\mathrm{o}}$ changes. The first $4 \mathrm{sec}$ of these responses are shown in Fig. 2B. The initial transient potential is the b-wave which has negative polarity when recorded intraretinally in the distal retina. The b-wave is followed by the positive cwave. After the c-wave reached its maximum (in 3-4 seconds), the potential returned to baseline, reflecting light-evoked changes of extracellular $\mathrm{K}^{+}$concentration $\left(\left[\mathrm{K}^{+}\right]_{0}\right)$ which "reaccumulated" after an initial decrease (Steinberg et al., 1980). All these voltage changes happen in the first 30 seconds of light stimulation; after that the potential does not change until light offset. In contrast, $\left[\mathrm{H}^{+}\right]_{\mathrm{o}}$ presented in Fig. 2A, left column, continues to decrease at increasing stimulus durations, demonstrating the slow development of the metabolic component of the $\mathrm{H}^{+}$response. Additionally, much faster $\left[\mathrm{H}^{+}\right]_{\mathrm{o}}$ changes were also recorded right after light onset. In fact, during the first $4 \mathrm{sec}$ of light stimulation the polarity of the $\left[\mathrm{H}^{+}\right]_{\mathrm{o}}$ response changes 3 times as seen in Fig. 2B: the initial acidification peaking around $50 \mathrm{~ms}$, then an alkalinization during the first second, then a partial second acidification when $\left[\mathrm{H}^{+}\right]_{\mathrm{o}}$ recovered to pre-stimulus level. Finally, after 9-10s, there was a steady late alkalinization (Fig. 2A) that took minutes to bring $\left[\mathrm{H}^{+}\right]_{\mathrm{o}}$ to the light-adapted level.

The multi-phasic changes of $\left[\mathrm{H}^{+}\right]_{\mathrm{o}}$ in the first few seconds of light are too early to be metabolic. These are the electrogenic $\left[\mathrm{H}^{+}\right]_{0}$ changes, described further below.

\subsection{Comparison of the light-induced changes of $\left[\mathrm{H}^{+}\right]_{0}$ and $\left[\mathrm{K}^{+}\right]_{0}$}

The electrogenic light-induced changes of $\left[\mathrm{H}^{+}\right]_{\mathrm{o}}$ recorded in different retinal layers are presented in Figure 3B. For comparison, the light-induced changes of $\left[\mathrm{K}^{+}\right]_{\mathrm{o}}$ in intact rat retina presented in Figure 3A. The light-induced changes of $\left[\mathrm{K}^{+}\right]_{\mathrm{o}}$ are well described in the retinas of different species (Dick and Miller, 1985; Dick et al., 1985; Karwoski and Proenza, 1978; Kline et al., 1978; Oakley and Green, 1976; Steinberg et al., 1980) and the mechanisms responsible for $\left[\mathrm{K}^{+}\right]_{\mathrm{o}}$ changes are well explained (Matsuura et al., 1978). It is also well understood that the differences in polarity and dynamics of $\left[\mathrm{K}^{+}\right]_{\mathrm{o}}$ changes recorded in different retinal layers are determined by the character of the light-induced electrical reactions of retinal neurons located there (Dmitriev et al., 1999a). The sustained hyperpolarization of the photoreceptors governs the slow steady decrease of $\left[\mathrm{K}^{+}\right]_{\mathrm{o}}$ in distal retina, while transient depolarization of inner retinal neurons is accompanied by the faster increase of $\left[\mathrm{K}^{+}\right]_{\mathrm{o}}$ in proximal layers.

In contrast, light-induced changes of $\left[\mathrm{H}^{+}\right]_{\mathrm{o}}$ (Fig. 3B) demonstrated remarkable similarity throughout the retina. In spite of different polarity and dynamics of the light-induced responses generated by the photoreceptors, horizontal, bipolar, amacrine, and ganglion cells, light stimulation led to similar $\left[\mathrm{H}^{+}\right]_{\mathrm{o}}$ changes at all retinal depths: the initial acidification and the subsequent alkalinization. These changes were not identical in different retinal layers: the initial acidification was slightly larger in distal retina than in proximal, and the alkalization was slightly larger and slower in proximal retina than in distal. However, the lack of substantial differences, such as was shown for $\left[\mathrm{K}^{+}\right]_{\mathrm{O}}$ changes (Fig. 3A), was rather surprising. One also should note the huge difference in absolute values of changes for $\left[\mathrm{K}^{+}\right]_{\mathrm{o}}$ 
and $\left[\mathrm{H}^{+}\right]_{\mathrm{o}}$ - about $1 \mathrm{mM}$ and $2.5 \mathrm{nM}$, respectively, i.e. more than 400,000 times. But this difference is not so dramatic if light-induced $\left[\mathrm{K}^{+}\right]_{\mathrm{o}}$ and $\left[\mathrm{H}^{+}\right]_{\mathrm{o}}$ changes are compared to their steady state level. Then they are about $20 \%$ for $\left[\mathrm{K}^{+}\right]_{\mathrm{o}}$ and $5 \%$ for $\left[\mathrm{H}^{+}\right]_{\mathrm{o}}$.

\subsection{Comparison of light-induced changes of $\left[\mathrm{H}^{+}\right]_{0}$ in retinae of control and diabetic rats}

The electrogenic light-induced changes of $\left[\mathrm{H}^{+}\right]_{0}$ recorded in retinae of diabetic rats had the same dynamics throughout the whole depth of the retina as those recorded in control rats (Fig. 4). The amplitudes of the initial acidification (measured at maximum) and following alkalinization (measured at the end of the $2.5 \mathrm{sec}$ light stimulus) also were not meaningfully different between diabetic and control animals (Fig. 5). Diabetics tended to have a little larger initial acidification in both the distal retina (in the subretinal space $20-40 \mu \mathrm{m}$ from RPE, diabetics: $2.71 \pm 0.08 \mathrm{nM}, \mathrm{n}=68$, controls: $2.49 \pm 0.21 \mathrm{nM}, \mathrm{n}=19$, here and below: mean \pm s.e.m., $\mathrm{n}=$ number of penetrations) and proximal retina (in the inner part of IPL, diabetics: $0.99 \pm 0.07 \mathrm{nM}, \mathrm{n}=53$, controls: $0.83 \pm 0.10 \mathrm{nM}, \mathrm{n}=16$ ). Diabetics tended to have a little smaller alkalinization at both locations (in distal retina, diabetics: $-0.73 \pm 0.07 \mathrm{nM}$, $\mathrm{n}=68$, controls: $-1.01 \mathrm{E} \pm 0.19 \mathrm{nM}, \mathrm{n}=19$; in proximal retina, diabetics: $-1.45 \pm 0.08 \mathrm{nM}$, $\mathrm{n}=53$, controls: $-1.50 \pm 0.17 \mathrm{nM}, \mathrm{n}=16)$ ) but none of these differences between control and diabetic animals were statistically significant (t-test, $\mathrm{P}>0.05$ ).

\subsection{Light-induced changes of $\left[\mathrm{H}^{+}\right]_{0}$ in the RPE and choriocapillaris}

While the light-induced $\left[\mathrm{H}^{+}\right]_{\mathrm{O}}$ changes were similar throughout whole depth of the neural retina, they were quite different when measured in the RPE layer and just behind it, in the choriocapillaris. Fig. 6A shows 6 sets of recordings ( $a, b$, and $c$ for controls, and $d, e$, and $f$ for diabetics), with the lower recordings of each set obtained in the most distal part of the photoreceptor layer. These lower recordings in the retina are similar to those described in Figs. 3B and 4, and they are presented here for comparison. As before, the LERG recordings made simultaneously with the $\mathrm{H}^{+}$recordings are shown in the right column. The main focus of the Fig. 6A is on the upper recordings in each set, which were obtained in the RPE layer or in the choroid, just 15 to $30 \mu \mathrm{m}$ deeper than the lower recordings. Occasionally we were able to record $\left[\mathrm{H}^{+}\right]_{\mathrm{o}}$ in the thin layer of RPE, as indicated by the inverted c-wave of the LERG in recordings $c$ and $f$. These recordings were most likely in the extracellular space between the lateral membranes of the epithelial cells just after passing the tight junctions, rather than intracellular, because the electrode tip was probably too large for intracellular recording. In that location, the light stimulation caused an increase in $\left[\mathrm{H}^{+}\right]_{0}$ that was far larger than in the retina in both controls and diabetics (Fig. 6A, $c$ and $f$ ). The amplitude of these $\left[\mathrm{H}^{+}\right]_{0}$ changes varied from 4.9 to $14.1 \mathrm{nM}$ and was on average higher in diabetics $(9.88$ $\pm 1.26 \mathrm{nM}, \mathrm{n}=7)$ than in controls $(7.58 \pm 0.58 \mathrm{nM}, \mathrm{n}=5)$, although the difference was not statistically significant (t-test, $\mathrm{P}>0.05$ ). However, a striking difference between light-induced $\left[\mathrm{H}^{+}\right]_{\mathrm{o}}$ changes in controls and diabetics was observed in the thin layer $(10-15 \mu \mathrm{m})$ just distal to the basal membrane of the RPE, where the ERG was nearly absent (recordings $a, b, d$ and e). In control rats, choroidal $\left[\mathrm{H}^{+}\right]_{\mathrm{o}}$ either did not change (Fig. 6A, a recordings) or sometimes decreased (Fig. 6A, $b$ recordings). In contrast, diabetic rats demonstrated either no change or an increase in choroidal $\left[\mathrm{H}^{+}\right]_{\mathrm{o}}$ (Fig. 6A, recordings $d$ and $e$, respectively). When the choroidal $\left[\mathrm{H}^{+}\right]_{\mathrm{o}}$ changes in the retinae of control and diabetic rats were averaged, 
the difference was obvious: the choroidal $\left[\mathrm{H}^{+}\right]_{\mathrm{o}}$ increased in diabetics $(1.34 \pm 0.20 \mathrm{nM}$, $\mathrm{n}=69)$, but decreased in control animals $(-0.58 \pm 0.21 \mathrm{nM}, \mathrm{n}=19)$ (Fig. 6B).

The difference between diabetic and control animals is further emphasized when all lightinduced changes of $\left[\mathrm{H}^{+}\right]_{\mathrm{o}}$ in the choroid are divided into 3 groups: increases, decreases and no change. Quantitatively, the change of $\left[\mathrm{H}^{+}\right]_{\mathrm{o}}$ was considered as an increase or decrease if its amplitude exceeded $1 \mathrm{nM}$, and as no change otherwise (for example, see Fig. 6A). In 5 out of 6 control rats, no changes in choroidal $\left[\mathrm{H}^{+}\right]_{\mathrm{o}}$ were recorded (26 recordings), but in the remaining animal, 4 out of 6 choroidal changes of $\left[\mathrm{H}^{+}\right]_{\mathrm{o}}$ were decreases $(12.5 \%$ of total in control group, Fig. 7A). Two diabetic rats showed no choroidal $\left[\mathrm{H}^{+}\right]_{\mathrm{o}}$ changes (19 recordings), but in 6 others an increase was the dominant polarity. Overall, among 70 recording of light-induced $\left[\mathrm{H}^{+}\right]_{\mathrm{o}}$ changes on the choroidal side of RPE in diabetics, $\left[\mathrm{H}^{+}\right]_{\mathrm{O}}$ increased in 53\% and did not change in 47\% (Fig. 7A).

An interesting result was obtained when the choroidal $\left[\mathrm{H}^{+}\right]_{\mathrm{o}}$ changes in individual diabetic rats were considered separately. The percentage of the time that light-induced choroidal $\left[\mathrm{H}^{+}\right]_{\mathrm{o}}$ increased in the penetrations obtained from each diabetic rat was calculated and plotted against the time after STZ injection for this animal (Fig. 7B). Unexpectedly, the rats in earlier stages of diabetes showed a higher percentage of increases in choroidal $\left[\mathrm{H}^{+}\right]_{\mathrm{O}}$ than rats in later stages (Fig. 7B).

\section{Discussion}

\subsection{Electrogenesis-caused light-induced changes of $\left[\mathrm{H}^{+}\right]_{0}$ in intact rat retina}

This is the first study concerning light-induced $\left[\mathrm{H}^{+}\right]_{\mathrm{o}}$ changes in intact rat retina. In the literature there are only 3 studies that specifically investigated light-dependent changes of $\left[\mathrm{H}^{+}\right]_{\mathrm{o}}$ in frog, toad, and cat (Borgula et al., 1989; Oakley, 1989; Yamamoto et al., 1992) and all used long lasting light stimulation (30 seconds to 5 minutes) generating predominantly metabolic $\mathrm{H}^{+}$responses. Changes of $\left[\mathrm{H}^{+}\right]_{\mathrm{o}}$ evoked by a short flash of light (2.5 seconds) utilized in this work were too fast to be metabolic in origin, and must reflect the transfer of an acid across the plasma membrane of retinal cells during their responses to light. These electrogenic responses must be due to changes membrane potentials, transmembrane conductances and ion transporter rates. Although the detailed analysis of the mechanisms of these changes and their possible cellular sources are beyond the scope of this paper, certain aspects of the matter are worthy to discuss.

The electrogenic light-induced changes of $\left[\mathrm{H}^{+}\right]_{\mathrm{O}}$ were bi-phasic: a transient initial acidification followed by alkalinization (Figs 3B, 4). The early acidification has been ignored previously as an electrical artifact (Borgula et al., 1989). The electrical asymmetry of double-barreled ion-selective microelectrodes due to the extremely high resistance of the ion-selective barrel (which could be 1000 times higher than the resistance of the reference barrel and comparable to the resistance of the insulating glass wall of these electrodes) makes these electrodes susceptible to generating electrical artifacts (see (Dmitriev et al., 1999a)) and the early acidification has a time course suspiciously similar to b-wave of ERG. However, in our experiments, an electrical pulse was sent across the eye after each light stimulus and recorded by both $\mathrm{H}^{+}$-selective and reference barrels. After subtraction of the 
reference voltage from the $\mathrm{H}^{+}$-selective voltage, no trace of the pulse was left in the resulting record, ensuring that the $\mathrm{H}^{+}$response was free from an artifact induced by differences in time constants of the two electrode barrels. It gives us reason to believe that the initial acidification consistently recorded after light onset is real. In the discussion below we will try to present possible explanations of our two principal findings concerning electrogenic light-induced $\left[\mathrm{H}^{+}\right]_{\mathrm{o}}$ changes: 1) the bi-phasic acidification-alkalinization time course of the changes, and 2) the persistence of this pattern of changes throughout the all of the retinal layers.

At the beginning, it is important to mention that a transmembrane transfer of acid results not only from transfer of $\mathrm{H}^{+}$itself, but also from transfer of other substances influencing $\left[\mathrm{H}^{+}\right]$, acids and bases, particularly $\mathrm{HCO}_{3}{ }^{-}$. $\mathrm{HCO}_{3}{ }^{-}$together with $\mathrm{CO}_{2}$ is responsible for most of the $\mathrm{H}^{+}$buffering in the nervous system and contributions of other buffers are insignificant (Fencl, 1986). Assuming that intra- and extracellular concentrations of highly diffusible $\mathrm{CO}_{2}$ are practically the same, the transmembrane concentration gradients for $\mathrm{H}^{+}$and $\mathrm{HCO}_{3}{ }^{-}$must be equal in size and opposite in direction. Since $\mathrm{pH}$ inside neuronal cells is usually considered to be about $0.2 \mathrm{pH}$ units lower than outside (for example, intracellular $\mathrm{pH} \approx 7.2$, extracellular $\mathrm{pH} \approx 7.4$ ), intracellular concentration of $\mathrm{H}^{+}\left(\left[\mathrm{H}^{+}\right]_{\mathrm{i}}\right)$ is approximately 1.6 times higher than $\left[\mathrm{H}^{+}\right]_{\mathrm{o}}$ so that the $\mathrm{H}^{+}$equilibrium potential is somewhere between -10 and -15 $\mathrm{mV}$. Accordingly, intracellular $\mathrm{HCO}_{3}{ }^{-}$concentration is 1.6 times lower than its extracellular concentration, and the equilibrium potential of $\mathrm{HCO}_{3}{ }^{-}$will also be from -10 to $-15 \mathrm{mV}$. The membranes of retinal cells are almost always hyperpolarized more than $-15 \mathrm{mV}$, which results in driving forces directed inward for $\mathrm{H}^{+}$and outward for $\mathrm{HCO}_{3}{ }^{-}$.

Because of the non-equilibrium distribution of $\mathrm{H}^{+}$and $\mathrm{HCO}_{3}{ }^{-}$, the opening of any channels permeable to these ions will lead to an inflow of $\mathrm{H}^{+}$and to an outflow of $\mathrm{HCO}_{3}{ }^{-}$that in both cases will result in alkalinization of extracellular space. Although activity dependent alkalinization due to channel-mediated $\mathrm{H}^{+}$flux was not convincingly proved anywhere in the nervous system, $\mathrm{HCO}_{3}{ }^{-}$-dependent alkaline shifts were described in numerous cases (for review see (Chesler, 2003)). The bicarbonate could be more important than $\mathrm{H}^{+}$simply because there are about 1 million $\mathrm{HCO}_{3}{ }^{-}$ions per $1 \mathrm{H}^{+}$in both extra- and intracellular space. Thus, there are many more available $\mathrm{HCO}_{3}{ }^{-}$ions to move through open channels than $\mathrm{H}^{+}$ ions.

The $\mathrm{HCO}_{3}{ }^{-}$-dependent alkalinization is well known to be associated with the GABAmodulated channels in brain and other parts of the nervous system of both invertebrates and vertebrates (for review see (Chesler and Kaila, 1992)). It is reasonable to predict that GABA-mediated conductance plays an important role in generating the rapid electrogenic changes of $\left[\mathrm{H}^{+}\right]_{\mathrm{o}}$ in the retina too. GABA-gated channels are known to be permeable mostly to $\mathrm{Cl}^{-}$, but $\mathrm{HCO}_{3}{ }^{-}$also can be a significant contributor (up to $40 \%$ of the current (Farrant and Kaila, 2007)). The presence of a GABA conductance has been demonstrated in every major retinal neuronal type, but if we have to choose the best candidate to generate GABArelated $\left[\mathrm{H}^{+}\right]_{\mathrm{o}}$ changes it would be bipolar cells. In contrast to the light-induced $\left[\mathrm{K}^{+}\right]_{\mathrm{o}}$ changes, which were different in dynamics and polarity in different retinal layers, the lightinduced $\left[\mathrm{H}^{+}\right]_{0}$ changes were remarkably similar throughout the whole retina. One possible explanation for this similarity could be that the GABA conductance of a single cell type, 
bipolar cells, which span much of the retina, is the largest contributor to the electrogenic changes. By analogy with the brain, an activity dependent (light-induced) opening of GABA channels on the bipolar cells will lead to efflux of $\mathrm{HCO}_{3}{ }^{-}$which will be responsible for a decrease in $\left[\mathrm{H}^{+}\right]_{\mathrm{o}}$.

But the situation in the retina is a bit more complicated than in brain. The bipolar cells possess GABA-gated channels in both OPL and IPL (Freed et al., 1987; Marc et al., 1978). Light-induced release of GABA in the IPL should lead to alkalinization there, but in the OPL it is expected that less GABA is released in the light, which should lead to acidification. Additional complications arise from the fact that different bipolar cells respond to light with different polarity. The light-induced hyperpolarization of the off-bipolar cells will enhance the driving force for $\mathrm{HCO}_{3}{ }^{-}$, while the depolarization of the on-bipolar cells will reduce it. Because of the relatively low $\mathrm{HCO}_{3}{ }^{-}$equilibrium potential, light-induced changes of bipolar cell membrane potentials could be an important factor, as depolarization from $-75 \mathrm{mV}$ to $-30 \mathrm{mV}$ will reduce the $\mathrm{HCO}_{3}{ }^{-}$driving force up to four fold. Such a complex system, where light-induced activity evokes both increasing and decreasing of GABA conductances multiplied by either hyper- or depolarization, is apparently capable of generating bi-phasic $\left[\mathrm{H}^{+}\right]_{\mathrm{O}}$ changes. The experimental fact that the initial increase of $\left[\mathrm{H}^{+}\right]_{\mathrm{O}}$ is larger in distal retina than in proximal and the following decrease of $\left[\mathrm{H}^{+}\right]_{\mathrm{o}}$ is larger in proximal retina than in distal (Fig. 5) is in agreement with the prediction that reduced GABA release in the OPL will favor acidification and elevated GABA release in the IPL will favor alkalinization.

Another potential contributor to the electrogenic light-induced changes of $\left[\mathrm{H}^{+}\right]_{\mathrm{O}}$ is the glial Müller cell, which covers even more of the retina than bipolar cells, stretching from the inner limiting membrane to outer limiting membrane. Müller cells do not have synaptic connections with retinal neurons that could be regulated by GABA, but they respond to light-evoked $\left[\mathrm{K}^{+}\right]_{\mathrm{o}}$ changes (Dick and Miller, 1985; Karwoski and Proenza, 1977). Importantly, Müller cells possess electrogenic $\mathrm{Na}^{+} / 2 \mathrm{HCO}_{3}{ }^{-}$cotransporters (Newman, 1996). It was demonstrated that $\mathrm{K}^{+}$evoked depolarization of the astrocytes in hippocampal slices elicited an interstitial acidosis generated by the $\mathrm{Na}^{+} / 2 \mathrm{HCO}_{3}{ }^{-}$cotransporter (Grichtchenko and Chesler, 1994). Similarly, Müller cells could influence retinal $\left[\mathrm{H}^{+}\right]_{\mathrm{o}}$ when their membrane potential is affected by light-induced $\left[\mathrm{K}^{+}\right]_{0}$ changes. Again, the situation in the retina appears to be more complicated than in brain, because $\left[\mathrm{K}^{+}\right]_{\mathrm{o}}$ increases in proximal retina and decreases in distal retina (see Fig. 3A). However, intracellular recording from Müller cells show that they depolarize during light, at least when the flashes are not too long (Dick and Miller, 1985; Karwoski and Proenza, 1977). Thus, we can expect some contribution from Müller cells to the increase of retinal $\left[\mathrm{H}^{+}\right]_{\mathrm{o}}$ due to extraction of $\mathrm{HCO}_{3}{ }^{-}$ from extracellular space by the electrogenic $\mathrm{Na}^{+} / 2 \mathrm{HCO}_{3}{ }^{-}$cotransporter. The acidification resulting from Müller cell activity should be relatively long lasting because of the slow time course of the Müller cell depolarization. But the fast time course of the recorded lightinduced initial acidification could be in fact the result of overlapping of acidification that started earlier and alkalinization that started later and overwhelmed the continuing tendency toward acidification. The increase and then decrease of the light-induced $\left[\mathrm{H}^{+}\right]_{\mathrm{o}}$ changes may represent different processes or different cell sources. 
The considerations above show that it is not unexpected to find complex light-evoked $\mathrm{H}^{+}$ changes, but there are more questions that are not easy to answer. For instance, why do the light-induced changes of $\left[\mathrm{H}^{+}\right]_{\mathrm{o}}$ in the subretinal space surrounding the distal part of the photoreceptors look so similar to the $\left[\mathrm{H}^{+}\right]_{\mathrm{o}}$ changes in other retinal layers, in spite of the difference in electrical responses and assortments of conductances and ion transporters of the photoreceptors, on one side, and bipolar cells and glial Müller cells, on other? Further investigation is necessary, but requires experimental manipulations that are difficult to perform on the intact animal.

\subsection{Light-induced changes of $\left[\mathrm{H}^{+}\right]_{0}$ near the basolateral membrane of the RPE}

One new experimental result was the recording of the light-induced $\left[\mathrm{H}^{+}\right]_{\mathrm{o}}$ changes in and behind the RPE cells. These experiments demanded undisturbed integrity of the retina-RPEchoroidal blood supply complex and could be done only on intact animals.

Occasionally during our penetrations, the $\mathrm{H}^{+}$-selective microelectrode just passed the tight junction level, but still stayed in the layer of RPE cells between their lateral membranes. The position of the electrode inside the RPE cell layer was confirmed by a characteristic slow negative electrical response to light, instead of a large slow positive response recorded in the retina, just $15 \mu \mathrm{m}$ proximally, or no electrical response at all in the choroid, $15 \mu \mathrm{m}$ distally (Fig. 6). This slow negative electrical response could be potentially interpreted in two different ways. One possibility is that this is an intracellularly recorded light-induced response of the RPE and its small amplitude (an order of magnitude smaller than the typical intracellular RPE response) could be attributed to damage to the RPE cell inflicted by the electrode penetration. We think this is unlikely. First, as we mentioned in the Methods, our electrode had a tip diameter of 5 to $8 \mu \mathrm{m}$, which is much larger than microelectrodes used for intracellular recordings (usually, a small fraction of one $\mu \mathrm{m}$ ). Second, although the crossing of the tight junction level is associated with a change in the electrode potential, we never observed a quick negative shift of the potential of -80 to $-90 \mathrm{mV}$ that is typical for penetration of the RPE plasma membrane. Third, the electrode potential remained stable after crossing tight junctions, as in other retinal layers, instead of gradually depolarizing, as expected for the membrane potential of a damaged cell. Thus, it seems more reasonable to assume that the electrode tip was still in extracellular space, and in these infrequent cases was positioned close to the lateral membrane of RPE. The resulting configuration would be similar to a loose patch recording and permitted us to obtain a diminished intracellular electrical response of a cell without breaking its plasma membrane. Consequently, we believe that the signal recorded by $\mathrm{H}^{+}$-selective barrel of the microelectrode reflected extracellular changes of $\mathrm{H}^{+}$. The light-induced changes of $\left[\mathrm{H}^{+}\right]_{0}$ recorded here, between the lateral membranes of the RPE cells were large (up to $14 \mathrm{nM}$ ) steady developing acidifications and represent the $\mathrm{H}^{+}$response of RPE on its choroidal side.

The ability of the RPE to transfer ions is well documented (Edelman et al., 1994; Lin and Miller, 1994) and there are at least two obvious pathways that should influence $\left[\mathrm{H}^{+}\right]_{\mathrm{o}}$ in the choroid (Fig. 8). The starting point for both pathways is the well known light-induced decrease of $\left[\mathrm{K}^{+}\right]_{0}$ on the apical side of the RPE. The upper left trace in Fig. 3A presents a sample of the early part of such $\left[\mathrm{K}^{+}\right]_{\mathrm{o}}$ changes. When the light-evoked decrease in $\left[\mathrm{K}^{+}\right]_{\mathrm{O}}$ 
happens in the distal retina, outside the apical membrane of the RPE, it is expected to slow the $\mathrm{Na}^{+} / \mathrm{K}^{+} / 2 \mathrm{Cl}^{-}$transporter located on the RPE apical membrane (green pathway in Fig. 8). The $\mathrm{Na}^{+} / \mathrm{K}^{+} / 2 \mathrm{Cl}^{-}$transporter is the mechanism responsible for pumping $\mathrm{Cl}^{-}$into the cell and creating an outward gradient for $\mathrm{Cl}^{-}$. Decelerating the transporter reduces this outward $\mathrm{Cl}^{-}$ gradient, in turn is expected to slow the $\mathrm{Cl}^{-} / \mathrm{HCO}_{3}{ }^{-}$transporter localized on the basolateral membrane. As result, $\left[\mathrm{HCO}_{3}{ }^{-}\right]_{\mathrm{o}}$ near the basolateral membrane of the RPE should increase and $\left[\mathrm{H}^{+}\right]_{\mathrm{o}}$ will decrease. Thus, light-induced changes of $\left[\mathrm{K}^{+}\right]_{\mathrm{o}}$ on the apical side of the RPE would lead through the $\mathrm{Cl}^{-}$pathway (marked green on Fig. 8) to alkalinization in the choroid. Also, however, the hyperpolarization of the apical membrane of the RPE resulting from the $\left[\mathrm{K}^{+}\right]_{\mathrm{O}}$ decrease should slow the $\mathrm{Na}^{+} / 2 \mathrm{HCO}_{3}{ }^{-}$-cotransporter because this transporter is electrogenic (contrary to transporters mentioned above) and sensitive to the membrane potential (yellow pathway in Fig. 8). This will decrease intracellular $\left[\mathrm{HCO}_{3}{ }^{-}\right]$, accelerate the $\mathrm{Cl}^{-} / \mathrm{HCO}_{3}{ }^{-}$transporter, reduce basolateral $\left[\mathrm{HCO}_{3}{ }^{-}\right]_{\mathrm{o}}$ and increase $\left[\mathrm{H}^{+}\right]_{\mathrm{o}}$ outside the basal membrane. Because we observed increased basolateral $\left[\mathrm{H}^{+}\right]_{\mathrm{o}}$, the $\mathrm{HCO}_{3}{ }^{-}$pathway appears to dominate.

\subsection{Changes in $\mathrm{H}^{+}$regulation associated with diabetes}

The electrogenic light-induced $\left[\mathrm{H}^{+}\right]_{\mathrm{o}}$ changes within the retinae and within the RPE layer of rats at early stages of diabetes (1-3 month) did not reveal any significant difference in time course (Fig. 4) or amplitude (Fig. 5) compared to those of control animals. However, $\left[\mathrm{H}^{+}\right]_{\mathrm{o}}$ changes recorded in a thin layer in the choroid just past the basal membrane of the RPE (Figs 6A, upper traces in $a, b, d$ and $e$ ) were noticeably affected $-\left[\mathrm{H}^{+}\right]_{\mathrm{o}}$ never increased there in control rats but increased in more than half the measurements in diabetics. This is the most important diabetes-related result of the paper. The position of the RPE tight junctional barrier can be identified precisely, because crossing it with the microelectrode was easily recognizable by the dramatic changes in the electrical potential and ERG.

These $\mathrm{H}^{+}$responses close to the RPE in the choriocapillaris result from interaction between the RPE and choroid. It is understandable that the stabilizing effect of blood flow should eliminate any $\left[\mathrm{H}^{+}\right]_{\mathrm{o}}$ changes somewhere deep in the choroid. According to our measurements, light-evoked $\mathrm{H}^{+}$changes disappeared by about $40-50 \mu \mathrm{m}$ past the RPE. However, when the electrode was positioned $10-20 \mu \mathrm{m}$ distal to the RPE some changes of $\left[\mathrm{H}^{+}\right]_{\mathrm{o}}$ could be recorded.

It is reasonable to assume that the light-induced $\left[\mathrm{H}^{+}\right]_{\mathrm{o}}$ increase recorded within the RPE layer (of both control and diabetic rats) reflects net acid transfer across the basolateral membrane of the RPE. We suggest that the absence of $\left[\mathrm{H}^{+}\right]_{\mathrm{o}}$ changes recorded at the choroidal side of the RPE in control rats reveals effective mechanisms of acid removal/ bicarbonate supply by the choroidal circulation. Correspondingly, the choroidal $\left[\mathrm{H}^{+}\right]_{\mathrm{O}}$ increase seen in most early diabetic rats points to a possible deficiency in those removal mechanisms, so that an acidification persists at some distance into the choroid. It was demonstrated previously that in the choriocapillaris of hyperglycemic rats (7-8 weeks after STZ injection) red blood cell flux and velocity were both significantly lower than the values in normal choriocapillaris (Braun et al., 2009). Also the choroidal blood flow in the foveal region significantly decreased in patients with diabetes (Nagaoka et al., 2004). Interestingly, 
according to our data, the acid removal by choroidal blood circulation was compromised most after 1 month of diabetes in rats and improved by 3 months (Fig. 7B). So it does not look like this defect in $\mathrm{H}^{+}$regulation progresses with diabetes development, but rather peaked earlier and then is somehow compensated to return to almost normal.

\section{Conclusions}

1. A brief flash of light $(2.5 \mathrm{sec})$ evokes bi-phasic changes in $\left[\mathrm{H}^{+}\right]_{\mathrm{o}}$ throughout the retina that originate probably from bipolar and/or Müller cells. Those changes are not altered noticeably at an early stage of diabetes in rats.

2. The light-induced $\left[\mathrm{K}^{+}\right]_{\mathrm{o}}$ decrease near the apical membrane of the RPE stimulates a prominent net acid release (due changes in movement $\mathrm{HCO}_{3}{ }^{-}$) across the RPE basolateral membrane. This RPE generated acidification does not appear to be affected by early diabetes.

3. The most dramatic diabetes-related effects are observed at the level of acid exchange between the RPE and the choroidal blood supply. Very effective in control animals, this exchange appears compromised in early diabetics so that a light-evoked acidification persists into the choriocapillaris.

\section{Acknowledgments}

Financial support

This work was supported by NIH grant R01EY021165

\section{Abbreviations}

$\begin{array}{ll}\text { RPE } & \text { retinal pigment epithelium } \\ \text { STZ } & \text { streptozotocin } \\ \text { LERG } & \text { local electroretinogram } \\ {\left[\mathbf{H}^{+}\right]_{\mathbf{o}}} & \text { extracellular hydrogen concentration } \\ {\left[\mathrm{K}^{+}\right]_{\mathbf{o}}} & \text { extracellular potassium concentration }\end{array}$

\section{References}

Ames A, Li YY, Heher EG, Kimble CR. Energy metabolism of rabbit retina as related to function: high cost of Na transport. J Neuroscience. 1992; 12:840-853. [PubMed: 1312136]

Borgula GA, Steinberg RH, Karwoski CJ. Light-evoked changes in extracellular pH in frog retina. Vision Research. 1989; 29:1069-1077. [PubMed: 2617854]

Braun RD, Wienczewski CA, Abbas A. Erythrocyte flow in choriocapillaris of normal and diabetic rats. Microvascular Research. 2009; 77:247-255. [PubMed: 19269298]

Budzynski E, Wangsa-Wirawan ND, Padnick-Silver L, Hatchell DL, Linsenmeier RA. Intraretinal pH in diabetic cats. Current Eye Research. 2005; 30:229-240. [PubMed: 15804749]

Chesler M. Regulation and modulation of $\mathrm{pH}$ in the brain. Physiological Reviews. 2003; 83:11831221. [PubMed: 14506304]

Chesler M, Kaila K. Modulation of pH by neuronal activity. Trends in Neurosciences. 1992; 15:396402. [PubMed: 1279865] 
Dick E, Miller RF. Extracellular $\mathrm{K}^{+}$activity changes related to electroretinogram components. I. Amphibian (I-type) retinas. The Journal of General Physiology. 1985; 85:885-909. [PubMed: 3926945]

Dick E, Miller RF, Bloomfield S. Extracellular $\mathrm{K}^{+}$activity changes related to electroretinogram components. II. Rabbit (E-type) retinas. The Journal of General Physiology. 1985; 85:911-931. [PubMed: 2410539]

Dmitriev A, Govardovskii V, Schwahn H, Steinberg R. Light-induced changes of extracellular ions and volume in the isolated chick retina-pigment epithelium preparation. Visual Neuroscience. 1999a; 16:1157-1167. [PubMed: 10614595]

Dmitriev A, Pignatelli A, Piccolino M. Resistance of retinal extracellular space to $\mathrm{Ca}^{2+}$ level decrease: implications for the synaptic effects of divalent cations. Journal of Neurophysiology. 1999b; 82:283-289. [PubMed: 10400957]

Dmitriev AV, Henderson D, Lau JC, Linsenmeier RA. Retinal acidosis at an early stage of diabetes in the rat. Investigative Ophthalmology \& Visual Science. 2014; 55:ARVO E-Abstract 1049.

Dmitriev, AV.; Henderson, D.; Linsenmeier, RA. Development of Diabetes-induced Acidosis in the Rat Retina. Society for Neuroscience Annual Meeting; 2015. p. Abstract 153.05

Dmitriev AV, Mangel SC. Circadian clock regulation of $\mathrm{pH}$ in the rabbit retina. The Journal of Neuroscience. 2001; 21:2897-2902. [PubMed: 11306641]

Dmitriev AV, Mangel SC. Retinal pH reflects retinal energy metabolism in the day and night. Journal of Neurophysiology. 2004; 91:2404-2412. [PubMed: 14960560]

Edelman JL, Lin H, Miller SS. Potassium-induced chloride secretion across the frog retinal pigment epithelium. American Journal of Physiology-Cell Physiology. 1994; 266:C957-C966.

Farrant M, Kaila K. The cellular, molecular and ionic basis of GABA A receptor signalling. Progress in Brain Research. 2007; 160:59-87. [PubMed: 17499109]

Fencl, V. Control of Breathing. Am Physiol Society; Bethesda, MD: 1986. Acid-Base Balance in Cerebral Fluids, Handbook of Physiology. The Respiratory System; p. 115-162.

Freed MA, Smith RG, Sterling P. Rod bipolar array in the cat retina: Pattern of input from rods and GABA-accumulating amacrine cells. Journal of Comparative Neurology. 1987; 266:445-455. [PubMed: 3693619]

Grichtchenko I, Chesler M. Depolarization-induced acid secretion in gliotic hippocampal slices. Neuroscience. 1994; 62:1057-1070. [PubMed: 7845586]

Hirasawa H, Kaneko A. pH changes in the invaginating synaptic cleft mediate feedback from horizontal cells to cone photoreceptors by modulating $\mathrm{Ca}^{2+}$ channels. The Journal of General Physiology. 2003; 122:657-671. [PubMed: 14610018]

Karwoski C, Proenza LM. Relationship between Muller cell responses, a local transretinal potential, and potassium flux. Journal of Neurophysiology. 1977; 40:244-259. [PubMed: 845622]

Karwoski CJ, Proenza LM. Light-evoked changes in extracellular potassium concentration in mudpuppy retina. Brain Research. 1978; 142:515-530. [PubMed: 638748]

Kleinschmidt J. Signal transmission at the photoreceptor synapse. Annals of the New York Academy of Sciences. 1991; 635:468-470. [PubMed: 1660251]

Kline RP, Ripps H, Dowling JE. Generation of b-wave currents in the skate retina. Proceedings of the National Academy of Sciences. 1978; 75:5727-5731.

Lau JC, Linsenmeier RA. Oxygen consumption and distribution in the Long-Evans rat retina. Experimental Eye Research. 2012; 102:50-58. [PubMed: 22828049]

Lin $\mathrm{H}$, Miller SS. pHi-dependent $\mathrm{Cl}-\mathrm{HCO}_{3}$ exchange at the basolateral membrane of frog retinal pigment epithelium. American Journal of Physiology-Cell Physiology. 1994; 266:C935-C945.

Marc RE, Stell WK, Bok D, Lam DM. GABA-ergic pathways in the goldfish retina. Journal of Comparative Neurology. 1978; 182:221-245. [PubMed: 212456]

Matsuura T, Miller W, Tomita T. Cone-specific c-wave in the turtle retina. Vision Research. 1978; 18:767-775. [PubMed: 307861]

Nagaoka T, Kitaya N, Sugawara R, Yokota H, Mori F, Hikichi T, Fujio N, Yoshida A. Alteration of choroidal circulation in the foveal region in patients with type 2 diabetes. British Journal of Ophthalmology. 2004; 88:1060-1063. [PubMed: 15258025] 
Newman EA. Acid efflux from retinal glial cells generated by sodium bicarbonate cotransport. The Journal of Neuroscience. 1996; 16:159-168. [PubMed: 8613782]

Oakley B. Extracellular pH in the isolated retina of the toad in darkness and during illumination. The Journal of Physiology. 1989; 419:353. [PubMed: 2516127]

Oakley B, Green DG. Correlation of light-induced changes in retinal extracellular potassium concentration with c-wave of the electroretinogram. Journal of Neurophysiology. 1976; 39:11171133. [PubMed: 1086346]

Padnick-Silver L, Linsenmeier RA. Effect of hypoxemia and hyperglycemia on $\mathrm{pH}$ in the intact cat retina. Archives of Ophthalmology. 2005; 123:1684-1690. [PubMed: 16344440]

Steinberg R, Oakley B, Niemeyer G. Light-evoked changes in $\left[\mathrm{K}^{+}\right]_{\mathrm{O}}$ in retina of intact cat eye. Journal of Neurophysiology. 1980; 44:897-921. [PubMed: 7441322]

Thoreson WB, Mangel SC. Lateral interactions in the outer retina. Progress in retinal and eye research. 2012; 31:407-441. [PubMed: 22580106]

Yamamoto F, Borgula GA, Steinberg RH. Effects of light and darkness on pH outside rod photoreceptors in the cat retina. Experimental Eye Research. 1992; 54:685-697. [PubMed: 1623953]

Yamamoto F, Steinberg RH. Effects of systemic hypoxia on $\mathrm{pH}$ outside rod photoreceptors in the cat retina. Experimental Eye Research. 1992; 54:699-709. [PubMed: 1623954] 


\section{Highlights}

Light-induced $\mathrm{pH}$ changes in the intact rat retina were measured by microelectrodes. In the retina, $\mathrm{pH}$ changes were not much different in control and early diabetic rats. In the choroid, $\mathrm{pH}$ changes were different in control and early diabetic rats.

Evacuation of retinal $\mathrm{H}^{+}$by the choroid appears to be compromised in early diabetics 
A

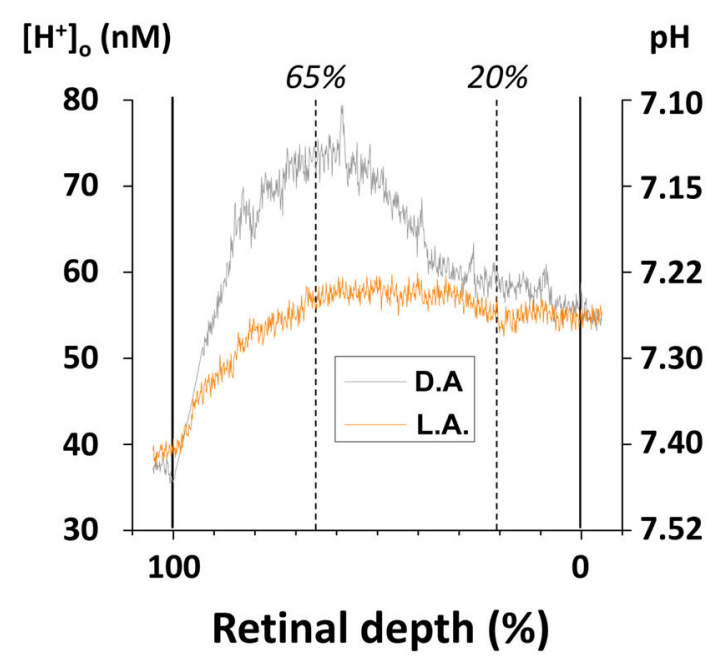

B

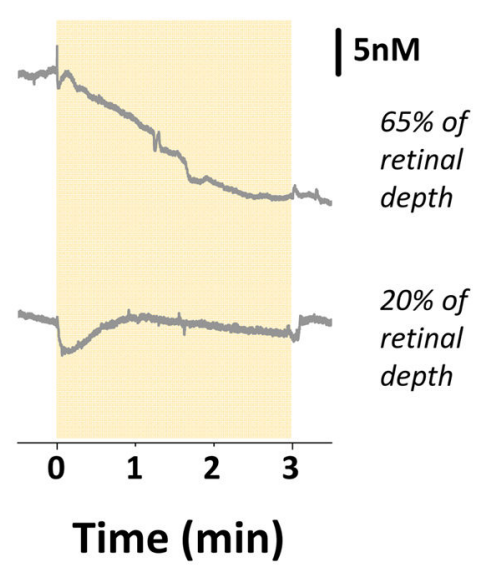

Fig. 1. Spatial (A) and temporal (B) changes of $\left[\mathrm{H}^{+}\right]_{0}$ in intact rat retina

A: Two profiles of the spatial distribution of $\mathrm{H}^{+}$across the same rat retina in dark-adapted (grey line) and light-adapted (orange line) conditions. The largest light-induced changes in $\left[\mathrm{H}^{+}\right]_{\mathrm{o}}$ were recorded at the level of the ONL-OPL ( $65 \%$ of the retinal depth), while in proximal retina $\left[\mathrm{H}^{+}\right]_{\mathrm{O}}$ was almost unchanged. B: Light-induced changes of $\left[\mathrm{H}^{+}\right]_{\mathrm{O}}$ in distal (65\% retinal depth) and proximal (20\% retinal depth) retina during 3 minutes of light stimulation (marked by yellow area). 
A

$\left[\mathrm{H}^{+}\right]_{\mathrm{o}}$

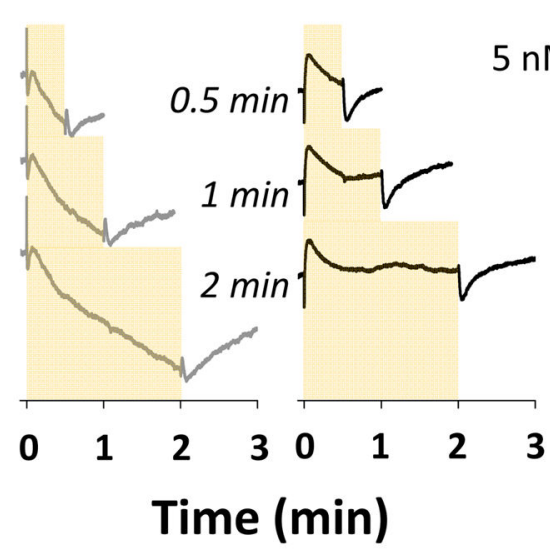

B

$\left[\mathrm{H}^{+}\right]_{\mathrm{o}}$ LERG

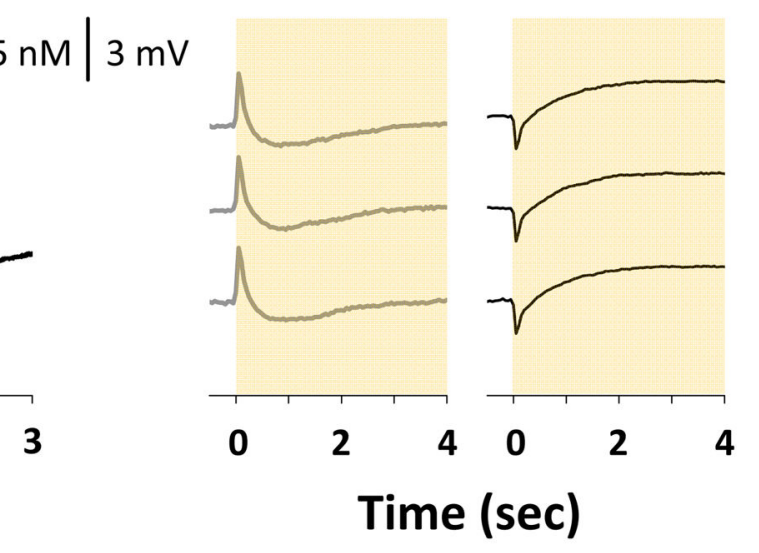

Fig. 2. Slow (metabolic, A) and fast (electrogenic, B) light-induced changes in retinal $\left[\mathrm{H}^{+}\right]_{\mathrm{o}}$ A: Light-induced changes of $\left[\mathrm{H}^{+}\right]_{\mathrm{o}}$ (left column) and associated LERG recordings (right column) in distal retina ( $67 \%$ of retinal depth) evoked by light stimulation of increasing duration $(0.5,1$ and 2 minutes, marked by yellow area and additionally by times noted near the records). Light onset is at time zero. B: The first 4 seconds of the same records. 
A
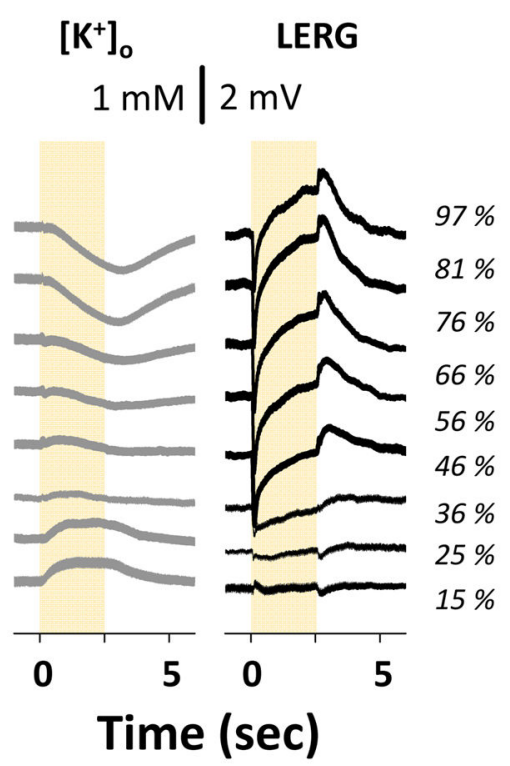

B
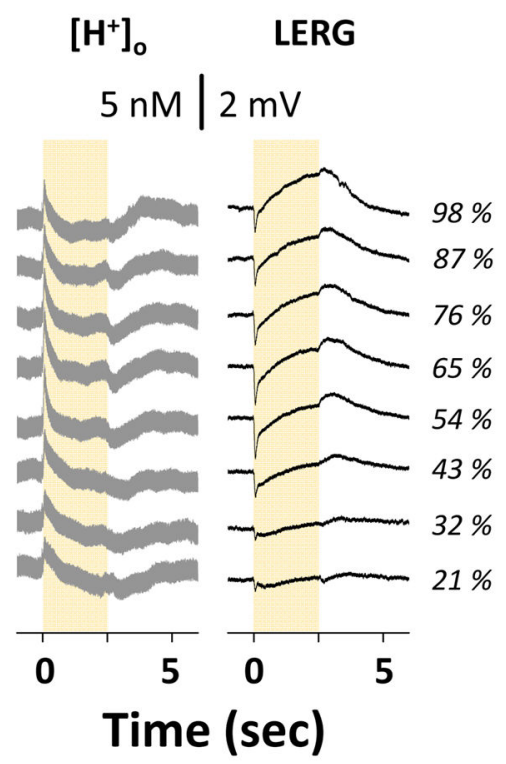

Fig. 3. Light-induced changes in $\left[\mathrm{K}^{+}\right]_{\mathrm{o}}(\mathrm{A})$ and $\left[\mathrm{H}^{+}\right]_{\mathrm{o}}(\mathrm{B})$ in different layers of rat retina The left column of traces in both parts of the figure is light-induced changes of extracellular ion concentrations $\left(\mathrm{K}^{+}\right.$in part $\mathrm{A}, \mathrm{H}^{+}$in part $\left.\mathrm{B}\right)$. The right column in both parts of the figure is LERGs simultaneously recorded at the same percent retinal depths, shown on the right of the records. Yellow bars indicate the duration of illumination. 

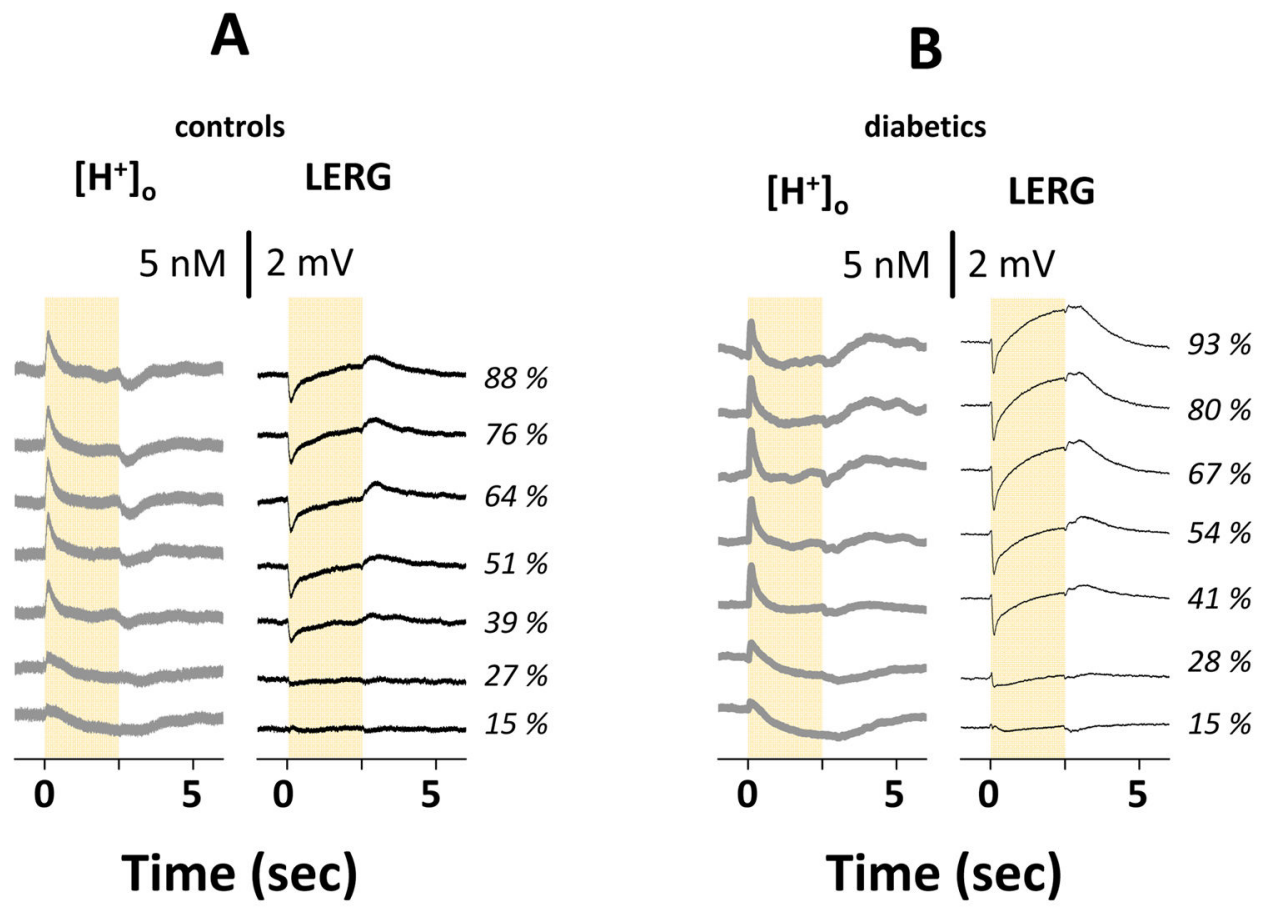

Fig. 4. Light-induced $\left[\mathrm{H}^{+}\right]_{0}$ changes in the retinae of control (A) and diabetic (B) rats The left column of traces in both parts of the figure shows light-induced changes of $\left[\mathrm{H}^{+}\right]_{\mathrm{O}}$. The right column in both parts of the figure shows LERGs simultaneously recorded at the same percent retinal depths, shown on the right of the records. Yellow bars indicate the duration of illumination. 


\section{$\Delta\left[\mathrm{H}^{+}\right]_{0}(\mathrm{nM})$}

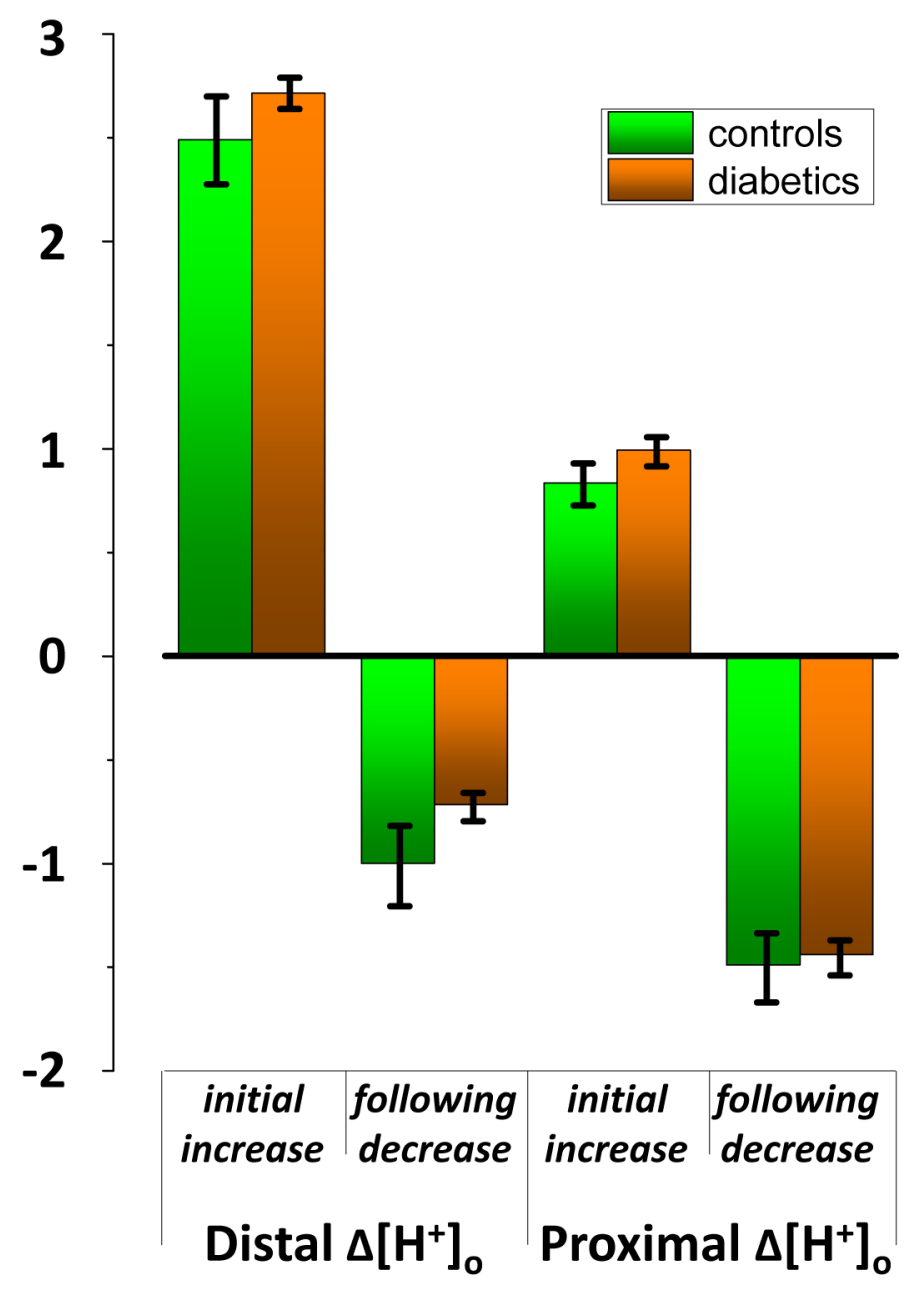

Fig. 5. Quantitative comparison of light-induced changes in $\left[\mathrm{H}^{+}\right]_{0}$ in the retinae of control and diabetic rats

Bars represent the amplitude (mean \pm s.e.m.) of the initial increase (measured at the peak) and following decrease (measured just before light offset) of light-induced $\left[\mathrm{H}^{+}\right]_{\mathrm{o}}$ changes in distal ( $85-95 \%$ of retinal depth) and proximal $(20-25 \%$ of retinal depth) retina. Green bars - controls, orange bars - diabetics. 
A

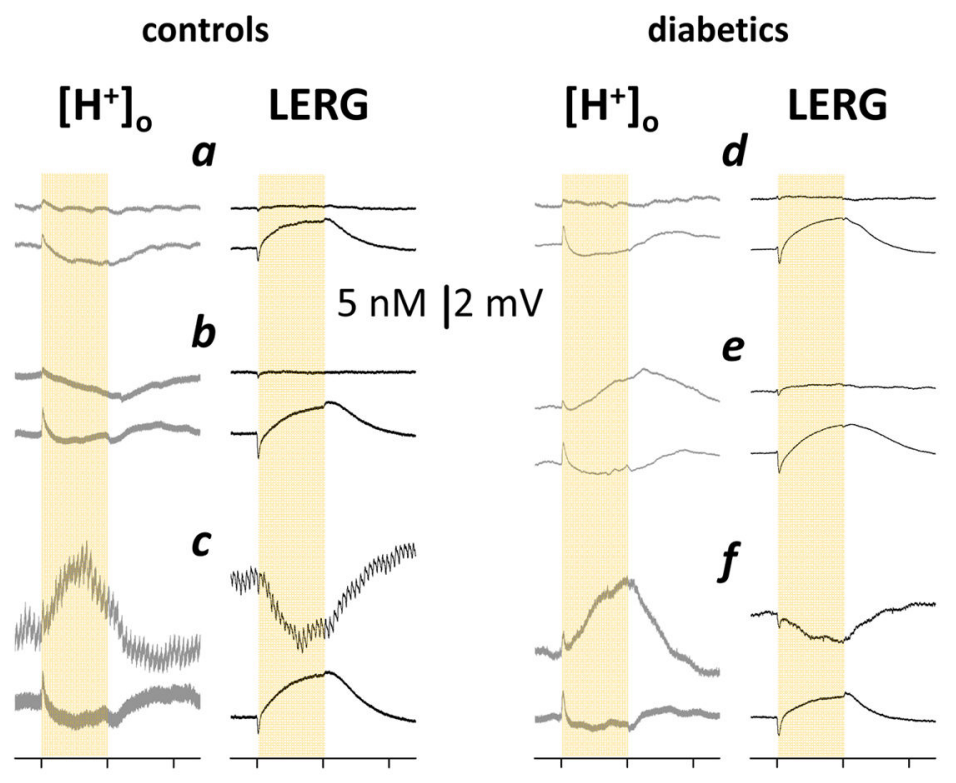

B

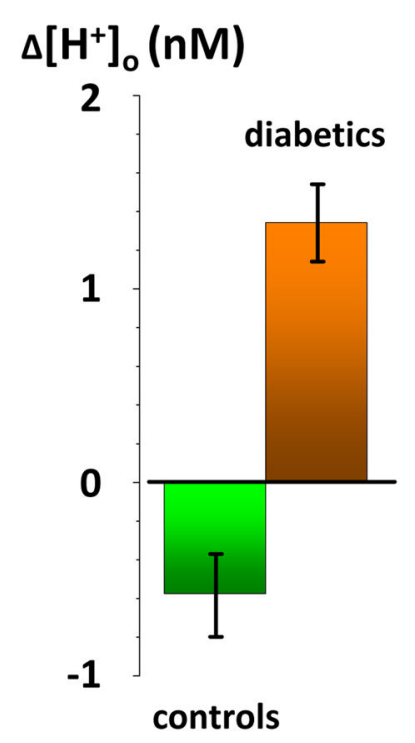

Fig. 6. Light-induced changes of $\left[\mathrm{H}^{+}\right]_{0}$ in the retina, RPE and choroid of control and diabetic rats

The recordings in part $\mathbf{A}$ are grouped in 6 sets of 4. Each set consists of traces (changes of $\left[\mathrm{H}^{+}\right]_{\mathrm{o}}$ on the left and LERG on the right) recorded in the retina, just before penetration of the tight junction layer of the RPE (lower records in each set), and just after the penetration, 15 to $30 \mu \mathrm{m}$ deeper (upper records). In sets $a, b, d$, and $e$, the upper pairs of the traces were obtained just distal to the RPE in the choroid where the LERG was essentially absent. In the upper records of sets $c$ and $f$ the microelectrode happened to be positioned between RPE cells near their lateral membranes. Data on the left (sets $a, b$, and $c$ ) obtained in control rats; data on the right (sets $d, e$, and $f$ ) obtained in diabetic rats. The bar graph in part $\mathbf{B}$ represents the average amplitude of $\left[\mathrm{H}^{+}\right]_{\mathrm{o}}$ changes recorded in the choroid near the basal side of the RPE (mean \pm s.e.m.). 

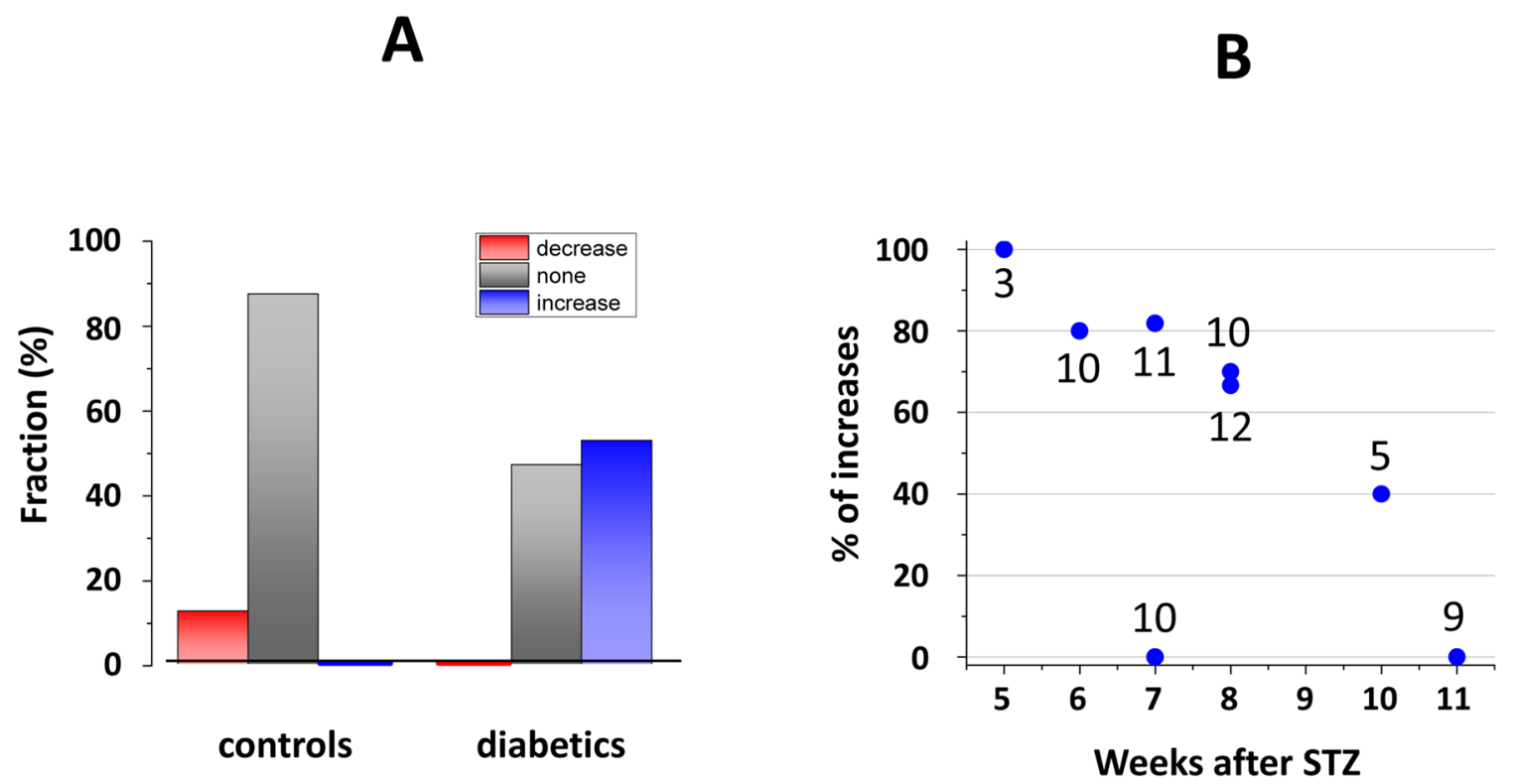

Fig. 7. Quantitative comparison of light-induced changes in choroidal $\left[\mathrm{H}^{+}\right]_{\mathrm{o}}$ of control and diabetic rats

A: Bar graphs representing fractions (in \%) of the decreases (red), the increases (blue) and the absence of measurable changes (grey) in total recordings of $\left[\mathrm{H}^{+}\right]_{\mathrm{O}}$ made in the choroid near RPE of control (left) and diabetic (right) rats. B: Fraction (in \%) of the increases in all $\left[\mathrm{H}^{+}\right]_{\mathrm{O}}$ recordings in choroid of individual diabetic rats plotted against time after STZ injection for each animal. 


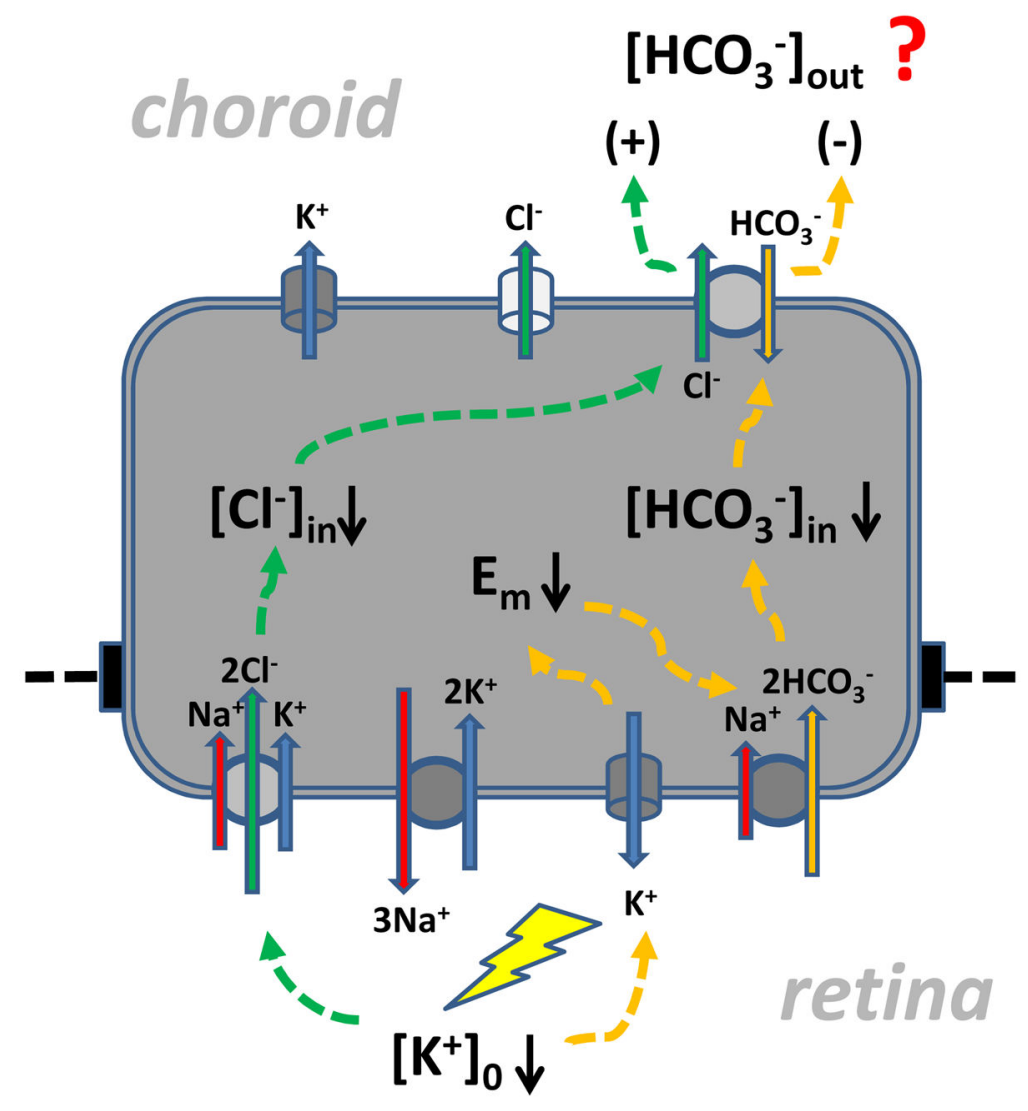

Fig. 8. Hypothetical mechanism capable of generating light-induced changes in choroidal $\left[\mathrm{H}^{+}\right]_{\mathbf{o}}$ Schematic based on known transporters (Edelman et al., 1994; Lin and Miller, 1994) to illustrate how $\left[\mathrm{HCO}_{3}{ }^{-}\right]_{\mathrm{O}}$ at the basal (choroidal) side of the RPE could be affected by the light-induced changes of $\left[\mathrm{K}^{+}\right]_{\mathrm{o}}$ on the apical side of the RPE. The principal transmembrane systems of ionic transport in RPE are presented as a cylinders for the channels and as circles for the transporters. The colored solid straight arrows represent ionic fluxes $\left(\mathrm{Na}^{+}-\mathrm{red}, \mathrm{K}^{+}-\right.$ blue, $\mathrm{Cl}^{-}$- green, $\mathrm{HCO}_{3}{ }^{-}$- yellow) directed as expected under dark-adapted conditions. The lengths of the arrows roughly represent the relative size of corresponding ionic fluxes. The dashed curved arrows show interactions between the components of the system expected to change transport through the basal $\mathrm{Cl}^{-} / \mathrm{HCO}_{3}{ }^{-}$exchanger and thereby alter $\left[\mathrm{H}^{+}\right]_{\mathrm{o}}$ through changes in $\left[\mathrm{HCO}_{3}{ }^{-}\right]_{\mathrm{O}}$. The mechanism for modulating $\mathrm{Cl}^{-}$(green) or $\mathrm{HCO}_{3}^{-}$(yellow) via intracellular changes are shown separately. Some of the components do not participate directly in either pathway, but their presence is important for stability of the system. 